\title{
ECONOMICAL OPERATION OF DRIP IRRIGATION SYSTEM WITH RICE STRAW MULCHING
}

\author{
E.M. Khalifa* and M.K. El-Nemr**
}

\begin{abstract}
A field experiment has taken place in Wahet El-Nagah farm, Khatatba village, Menoufia governorate, Egypt in the year 2005, in order to use the ability of rice-straw mulching as cheap farm residue, to reduce the effect of deficit irrigation on highly sensitive crop for water deficit. Split plot design consisted of soil surface covering case (rice straw mulching $\left(500 \mathrm{~g} / \mathrm{m}^{2}\right)$ and no-mulch) as main plot with four amounts of applied water 70, 80, 90, and $100 \%$ of $E T_{c}$ as sub-plot. Cucumber crop was irrigated by drip irrigation system under sandy soil conditions. Using rice straw mulch led to decrease the soil moisture reduction by 66, 57, 48.9, and $38 \%$ compared with nomulch treatments for the 70, 80, 90, and 100\% of ET respectively. All rice straw mulch treatments showed a productivity increase compared to nomulch. The maximum crop yield $8.24 \mathrm{Mg} / \mathrm{fed}$ was obtained under rice straw mulching and $100 \%$ of $E T_{c}$ percentage causing a $29.6 \%$ increase in productivity compared with the crop productivity obtained at the treatment of same amount of applied water under traditional conditions. Rice straw mulch led to increase water use efficiency (WUE) the maximum value of WUE under rice straw mulch was $6.55 \mathrm{~kg} / \mathrm{m}^{3}$ with $90 \%$ of $E T_{c}$ while it was 4.37 $\mathrm{kg} / \mathrm{m}^{3}$ under the same conditions with no-mulch. Maximum benefit-cost ratio, 2.92 was obtained under rice straw mulch with $90 \%$ while it was 2.86 for nomulch with $100 \%$. The study recommended using rice straw mulch with $90 \%$ of $E T_{c}$ to obtain the maximum product of unit of water and maximum economic benefit.
\end{abstract}

\section{INTRODUCTION}

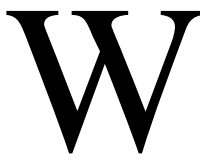

ater problem all over the world will lead to try to maximize the benefits of unit of water. Modern irrigation systems such as drip irrigation have a high efficiency and help to save water and increasing crop production. We should try to use any addition techniques that may help the irrigation system to reduce water losses and gives the most high possible crop productivity in addition to caring and viewing of economic side.

*Associate Professor, Agric. Eng. Dept., Fac. Of Agric., Kafrelsheikh Univ., Egypt.

**Assistant Professor, Agric. Eng. Dept., Fac. Of Agric., Kafrelsheikh Univ., Egypt. 
Drip irrigation system is widely used under Egyptian sandy soil conditions due to it has low initial costs, increased beneficial use of available water, enhanced plant growth and yield, decreased energy requirements. Organic mulch helps to preserve water in soil by reducing evaporation losses, moderates temperature of the root zone. Drip irrigation is compatible with mulching, because the grower can maintain optimum moisture under the mulch Olson, (1995).

Al-Wahaibi et al. (2007) found that mulching with date palm residues was superior in terms of tomato fruit yield and controlling increase in soil salinity and temperature as compared to black plastic mulch and control. Yang $\boldsymbol{e t}$ al. (2007) found that surface mulch had significant effect in reducing water evaporation and reducing soil salinity level of the desalinized plots planted with winter wheat. Kar and Kumara (2007) found that soil moisture depletion from potato plots decreased with straw surface mulching thus increasing plant growth and tuber production as compared to non-mulched plots that indicated higher soil moisture depletion. In their study of seven soil management practices In their study with corn, Bu et al. (2002) found that surface applied mulches resulted in reduced soil water loss by evaporation and in reduced salt accumulation on surface in addition to controlling weeds. Abd El-Kader et al. (2010) concluded that, mulching with rice straw for cowpea with a mixture of some micro-nutrients $(600 \mathrm{ppm})$ under clay soils lead to increased soil moisture content, soil temperature, root length, root dry weight, growth and yield measurements. Rice straw (as organic mulch) is inexpensive, available under Egyptian conditions, insulates well, and conserves moisture. In addition, it acts an environmental problem during the last five years in Egypt resulting from the harm way of its disposition (burning) because of the difficulties of using it as a commercial product for normal farmers so using it for mulching could offer a solution for this problem in addition to its benefits as an organic cheap mulch. Rahaman $\boldsymbol{e t}$ al. (2004) revealed that rice straw mulch increased potato yield average of two years than water hyacinth mulch. Deficit (or regulated deficit) irrigation is one way of maximizing water use efficiency (WUE) for higher yields per unit of irrigation water applied Kirda et al., (1999), it decreases irrigation system operation time that may give help to face water and fuel problem, but it needs to be managed well to avoid its effect on crop productivity which will be affected negatively with water reduction. Narayan et al. (1994) found 
that water use efficiency had increased from 2.23 to $2.63 \mathrm{~kg} / \mathrm{m}^{3}$ as a result of decreasing the irrigation level from 0.8 to 0.4 of cumulative pan evaporation of sweet pepper. The objectives of this work under sandy soil conditions were as follows:

1- Reduce system operation time via deficit irrigation.

2- Using rice straw mulching to avoid the effect of deficit irrigation without any highly costive treatments.

3- Study the expected productivity reduction significance.

4- Evaluate the effect of defecit irrigation on benefits-cost ratio for recommending an economic management method for drip irrigation system

\section{MATERIALS AND METHODS}

\section{Preparation of the experimental area}

A $30 \mathrm{~m}$ laterals containing built- in emitters $50 \mathrm{~cm}$ spacing along lateral and $150 \mathrm{~cm}$ between rows were used to irrigate cucumber crop (F1-Faris) during the successive summer season 2005 in sandy soil (Table 1).

Table.1:Some physical properties of the experimental soil.

\begin{tabular}{|c|c|c|c|c|c|c|}
\hline \multirow{2}{*}{ Depth, cm } & \multicolumn{5}{|c|}{ Soil physical and hydro-physical Characteristics } \\
\cline { 2 - 5 } & \multicolumn{2}{|c|}{ Particle size distribution } & & \multirow{2}{*}{ F.C, \%. } & P.W.P, \%. \\
\cline { 2 - 7 } & Sand, \% & Clay, \%. & Silt, \% & Texture & & \\
\hline $0-15$ & $\mathbf{8 9 . 6 9}$ & $\mathbf{0 . 4 7}$ & $\mathbf{9 . 8 4}$ & Sandy & $\mathbf{9 . 8}$ & $\mathbf{4 . 8}$ \\
\hline $15-30$ & $\mathbf{8 9 . 7 1}$ & $\mathbf{0 . 4 7}$ & $\mathbf{9 . 8 2}$ & Sandy & $\mathbf{1 0 . 2}$ & $\mathbf{5 . 0}$ \\
\hline $30-45$ & $\mathbf{8 8 . 5 4}$ & $\mathbf{3 . 2 1}$ & $\mathbf{8 . 2 5}$ & Sandy & $\mathbf{1 0 . 9}$ & $\mathbf{5 . 1}$ \\
\hline
\end{tabular}

F.C = Field capacity, and P.W.P= Permanent wilting point.

Table.2 shows emitter some emitter characteristics. The field work was carried out in a $60 \times 42 \mathrm{~m}^{2}$ experimental area. The final cultivated area slope was zero level.

Table.2: Used emitter characteristics

\begin{tabular}{|c|c|c|c|}
\hline $\begin{array}{c}\text { Manufacturer } \\
\text { name }\end{array}$ & Classification & Country of made & $\begin{array}{c}\text { Flow rate at } \\
\text { experimental } \\
\text { operating head }\end{array}$ \\
\hline Euro drip & Built-in & Egypt & $4.41 \mathrm{l} / \mathrm{h}$ \\
\hline
\end{tabular}

The soil and water chemical analysis showed that soil $\mathrm{pH}$ was 7.85 , therefore $40 \mathrm{~kg} / \mathrm{fed} \mathrm{of} \mathrm{sulfur} \mathrm{were} \mathrm{added} \mathrm{to} \mathrm{control} \mathrm{alkalinity} \mathrm{of} \mathrm{soil.} \mathrm{Electrical}$ conductivity of water was $0.8 \mathrm{dS} / \mathrm{m}$ while SAR (Sodium absorption ratio) was 2.55 so irrigation water can be used with out any expected problems for salinity or infiltration (FAO, 1980). Chisel plow (5 shares) hitched by a 
$33.58 \mathrm{~kW}(45 \mathrm{hp})$ tractor was used to remove residues of previous crop (Zea maize) and weeds. Before planting amounts of $20-75-100 \mathrm{~kg} /$ fed of N-P-K, respectively, were added during plowing operation. Cucumber crop was planted in 22/7/2005 with 3 seeds per pore (50 cm spacing) at $5 \mathrm{~cm}$ depth and after germination it was thinned to one plant / pore. A pesticide $2.5 \%$ Mefenoxam, and 40\% Copper was used $150 \mathrm{~g} / 100$ litres to defend plants against fungus infections. A pesticide contains active ingredient diethyl trichloro- pyridyl phosphoriothioate $480 \mathrm{~g} / \mathrm{l}$ were used to defend insects (Pachnoda fasciata) that attacked cucumber fruits. Primary tests were carried out to choose a suitable mulching density for rice straw .The compared thickness' were 2.5, 3.8 and $5 \mathrm{~cm}(1,1.5$ and 2 inches). Every thickness was one meter length. Mulching over $5 \mathrm{~cm}$ thickness was avoid to reduce mulching costs and over mulching problems. A soil moisture meter $2 \%$ accuracy was used to measure the soil moisture content after 6,12 , and 24 hours after reaching soil field capacity. This test was carried out in the field with separated lateral (30 m length) out of the main experiment area. Three positions on the previously mentioned outside lateral acting first, second and last thirds along lateral were chosen randomly to be mulched as replicates. According to the primary study the $5 \mathrm{~cm}$ thickness was chosen because it reduced the moisture loss as shown in Figure 1. The Rice straw mulch width was $60 \mathrm{~cm}$ with abundance $500 \mathrm{~g} / \mathrm{m}^{2}$.

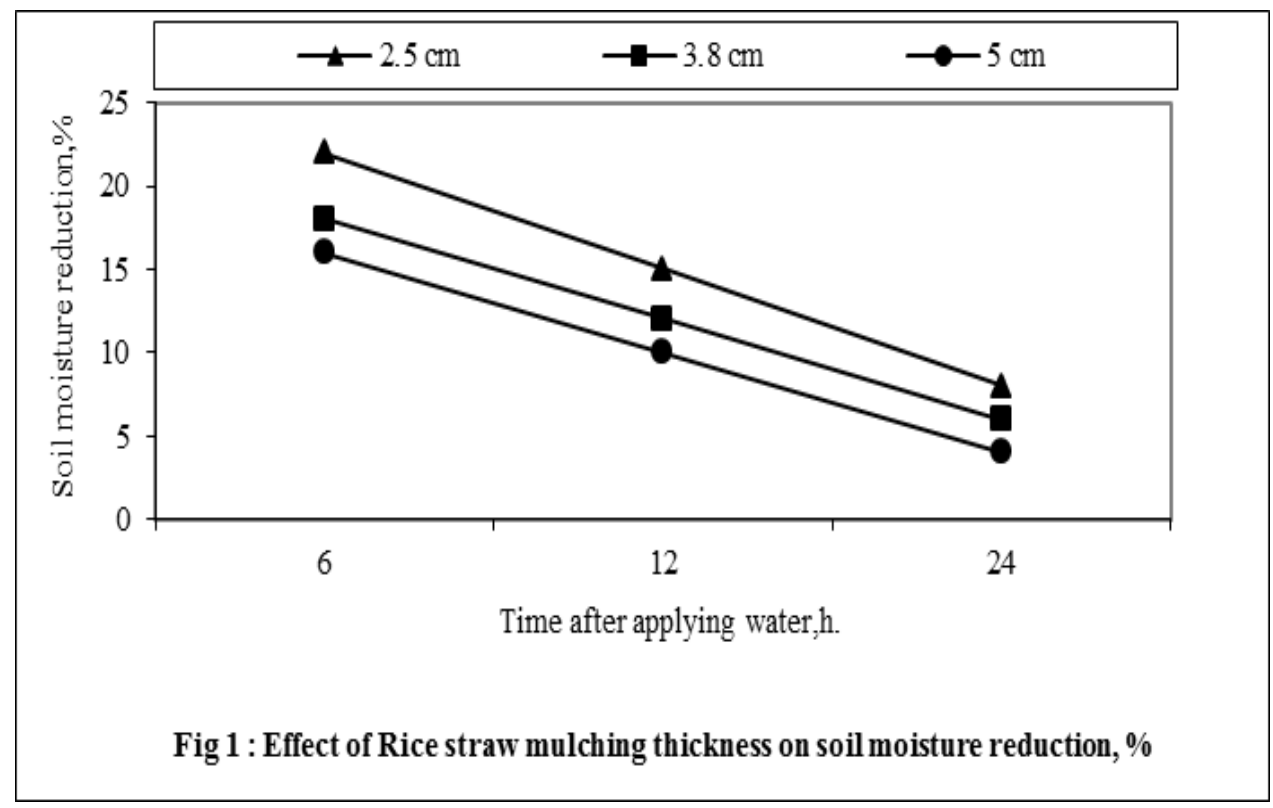




\section{Irrigation requirements}

Reference evapotranspiration was cited for the experimental area using CLIMWAT computer program FAO (1993). The cucumber crop water requirements $\left(\mathrm{ET}_{\mathrm{c}}\right)$ was calculated refering to Vermeiren and Jobling (1980). Crop factor values were $0.6,1$, and 0.75 for the first, second, and last third of growing season respectively FAO (1998). Reduction factor was calculated referring to Keller and Karmeli (1975). The reduction factor value was 1 .

\section{Experimental design.}

Under rice straw mulching and traditional conditions, 72 hs were tested as suitable intervals for sandy soil conditions with drip irrigation laterals. The space between emitters was $50 \mathrm{~cm}$ along lateral. Bulb valves (T-shape) were used after $30 \mathrm{~cm}$ from the beginning of each lateral to control water entry through the laterals. The main and sub-main pipes were P.V.C 4 and 2 inches diameter respectively. Four quantities of total crop water requirement $\left(\mathrm{ET}_{\mathrm{c}}\right)$ noted as $70,80,90$, and $100 \%$ were used to study the effect of deficit of irrigation water under mulching conditions on cucumber crop. Split plot design was used to perform statistical analysis and mean comparison. Mulch type act main plot while submain was the amount of applied water.

\section{Measurements:}

\subsection{Soil moisture content preservation:}

The soil moisture content was measured to study the effect of type of mulch on water preservation under different amounts of applied water. Soil moisture content horizons (0-5), (5-10), (10-15), (15-20), (20-25), and (25-30)cm vertically from the soil surface at different 4 times after irrigation 0 hours( directly after irrigation), 3 hours, 6 hours, and 9 hours. Gravitational method was used to express the moisture content. Soil samples from the mentioned depths were taken by an auger to find the sample moisture content. The average values of soil of moisture content were used to express root zone moisture. Moisture was calculated on dry base as follows :-

$$
\text { Soil moisture }=\frac{\text { Soil wet weight }- \text { Soil dry weight }}{\text { Soil dry weight }} * 100 \ldots \ldots 1
$$

Dry weight was found by taking wet weighed soil samples to laboratory and drying it on $105^{\circ} \mathrm{C}$ for 24 hours. 


\subsection{Yield productivity and Water use efficiency (WUE):}

One meter length $(1.5 \mathrm{~m}$ width) from each treatment were taken to find the crop productivity and replicated four times. Fruits were weighed on $10 \mathrm{~g}$ accuracy scale. The average of replicates were calculated, then it was multiplied in 2800 to act the crop yield per feddan ( 0.42 ha). Picking fruits starts when cucumber fruit reaches $12-14 \mathrm{~cm}$ long and/or $2 \mathrm{~cm}$ diameter.

Crop water productivity expression was used to express water use efficiency, which has been used to describe the relationship between cucumber crop production and the total amount of water used. It was determined by applying the following equation (Jensen, 1983):

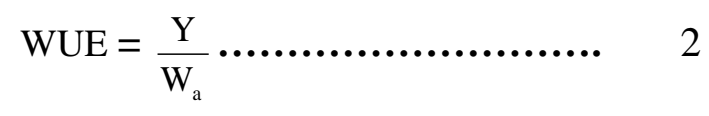

Where:-

$$
\begin{aligned}
& \text { WUE = water use efficiency, } \mathrm{kg} / \mathrm{m}^{3}, \mathrm{Y}=\text { total yield } \mathrm{kg} / \mathrm{fed} \\
& \mathrm{W}_{\mathrm{a}}=\text { total applied water, } \mathrm{m}^{3} / \mathrm{fed} .
\end{aligned}
$$

\subsection{Costs.}

The total cost of different treatments were calculated to study the effect of deficit irrigation and using mulch on the benefit / cost ratio. The total costs were divided into two main parts, fixed costs and variable costs. Costs were cited from commercial prices of Egyptian market during the year 2005. Calculation of costs was in L.E (US\$ = 6.6 L.E during the study period). The economic area to study the benefit/cost ratio was 5 feddans $(2.1 \mathrm{ha})$. The pump power calculated as serving 5 feddans. The calculated pump power was $11.45 \mathrm{~kW}$ but a 11.19 horse power diesel pump price was used because of the non availability of such pumps have the exact calculated power. It was considered that the whole experimental area was covered with the same mulch when calculating mulch costs. The total costs were calculated referring to Buchanan and Cross 2002. The Capital cost included land leveling, and irrigation network components. The capital costs summation was 2700 L.E. The price of component at the end of operating life was $10 \%$ of its original price. Interest ratio was assumed $12 \%$. Taxes and insurance was $2 \%$ of the main price. Gasoline price was 0.6 L.E/l during the study time period. Fuel 
consumption $\left(\mathrm{F}_{\mathrm{c}}\right)$ was calculated Using the following formula (Kepner et al.,1980):-

$$
\mathrm{F}_{\mathrm{c}}=0.12 * \mathrm{P}_{\mathrm{E}} \ldots \ldots \ldots \ldots \ldots \ldots . .3
$$

Where: $\mathrm{P}_{\mathrm{E}}=$ Engine brake power, $\mathrm{hp}$

The oil and lubricant costs was assumed to be $15 \%$ of fuel costs (Kepner et al.,1980). Repairs and maintenance was assumed to be $100 \%$ of annual depreciation cost .The price at the end of the expected life, interest ratio, and repairs and maintenance calculation assumptions were referring to (ElDnasoury,2001). The real daily salary of a labor in the study area was 8 pounds/day for 8 hours daily.The benefits of cucumber crop was considered as the price of selling from the farm. It did not include any transport costs .The price was $1.6 \mathrm{~L} . \mathrm{E} / \mathrm{kg}(0.24 .2 \mathrm{US} \$ / \mathrm{kg})$ depending on the commercial prices of year 2005. The Benefit- cost ratio $(\mathrm{B} / \mathrm{C})$ is the benefit of productivity selling divided by the total production costs.

\section{RESULTS AND DISCUSSION}

\section{Soil moisture preservation}

Table 3 shows the values of soil moisture content reduction for $45 \mathrm{~cm}$ depth measured during 9 hours after irrigation. The soil moisture loss increased by increasing amount of applied water, that may happened because of the reversible relationship between soil moisture stress and soil moisture content. Usage of rice straw mulch led to decrease the soil moisture reduction by 66 , 57, 48.9, 38 percent compared to No-mulch conditions for the 70, 80, 90, and $100 \%$ of $\mathrm{ET}_{\mathrm{c}}$ respectively.

Table.3: Soil moisture reduction percentage after 9 hours from the end of irrigation.

\begin{tabular}{|c|c|c|}
\hline Amount of applied water, $\mathbf{\%}_{\mathbf{E}}$ & Rice straw & No-Mulch \\
\hline 70 & 0.88 & 2.6 \\
\hline 80 & 1.49 & 3.5 \\
\hline 90 & 2.45 & 4.8 \\
\hline 100 & 3.4 & 5.5 \\
\hline
\end{tabular}




\section{Crop productivity.}

Results listed in Table 4 show that the maximum productivity of crop yield $8.24 \mathrm{Mg} /$ fed was obtained under rice straw mulch with $100 \% \mathrm{ET}_{\mathrm{c}}$, while the maximum productivity under traditional conditions was $5.8 \mathrm{Mg} / \mathrm{fed}$ for the same amount of applied water. In general, results showed that the rice straw treatments were higher than traditional conditions. Increasing applied water from 70 to $100 \%$ will lead to increase the crop productivity by $24 \%$ compared with $33 \%$ for no-mulch conditions. That may be due to the water preservation by rice straw mulch which decreased the effect of water deficit. Mean comparison showed that there were no significant differences between all amounts of applied water under rice straw mulch.

Table 4: Mean cucumber yield production (Mg/fed) under different irrigation water regime treatments.

\begin{tabular}{|c|c|c|}
\hline Amount of applied water, \%ETc & Rice straw & No- mulch \\
\hline 70 & $6.24 \mathrm{a}-\mathrm{d}$ & $3.86 \mathrm{~d}$ \\
\hline 80 & $6.83 \mathrm{a}-\mathrm{c}$ & $4.57 \mathrm{~cd}$ \\
\hline 90 & $8.08 \mathrm{ab}$ & $5.4 \mathrm{~b}-\mathrm{d}$ \\
\hline 100 & $8.24 \mathrm{a}$ & $5.8 \mathrm{a}-\mathrm{d}$ \\
\hline
\end{tabular}

L.S.D $=2.779$ at 0.05 level

\section{Water use efficiency (WUE):}

The resulted data of water use efficiency show that due to the increase in crop productivity under rice straw mulch, water use efficiency for all the amounts of applied water under rice straw mulch were greater than no-mulch amounts. The maximum value under rice straw mulch was $6.55 \mathrm{~kg} / \mathrm{m}^{3}$ with $90 \%$ of $\mathrm{ET}_{\mathrm{c}}$ while it was 4.37 under the same amount with no-mulch. That may be due to non-significant decrease in crop productivity with the decrease in applied water. Figure 2 shows a histogram to compare the water use efficiency under mulching and traditional conditions. 
Table.5: Water use efficiency for experimental treatments.

\begin{tabular}{|c|c|c|c|c|}
\hline & $\begin{array}{c}\text { Amount of } \\
\text { applied water, } \\
\text { \% ET }\end{array}$ & $\begin{array}{c}\text { Crop productivity, } \\
\text { Mg/fed }\end{array}$ & $\begin{array}{c}\text { Amount of applied } \\
\text { water, } \mathbf{m}^{\mathbf{3}} / \text { fed }\end{array}$ & $\begin{array}{l}\text { Water use efficiency, } \\
\qquad \mathrm{kg} / \mathrm{m}^{3}\end{array}$ \\
\hline \multirow{4}{*}{ 递 } & \begin{tabular}{|l|}
70 \\
\end{tabular} & 6.23 & 959.7 & 6.50 \\
\hline & 80 & 6.82 & 1096.8 & 6.22 \\
\hline & 90 & 8.07 & 1233.6 & 6.55 \\
\hline & 100 & 8.23 & 1371 & 6.01 \\
\hline \multirow{4}{*}{ 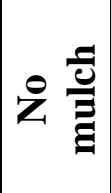 } & 70 & 3.85 & 959.7 & 4.01 \\
\hline & 80 & 4.56 & 1096.8 & 4.15 \\
\hline & 90 & 5.39 & 1233.6 & 4.37 \\
\hline & 100 & 5.80 & 1371 & 4.23 \\
\hline
\end{tabular}

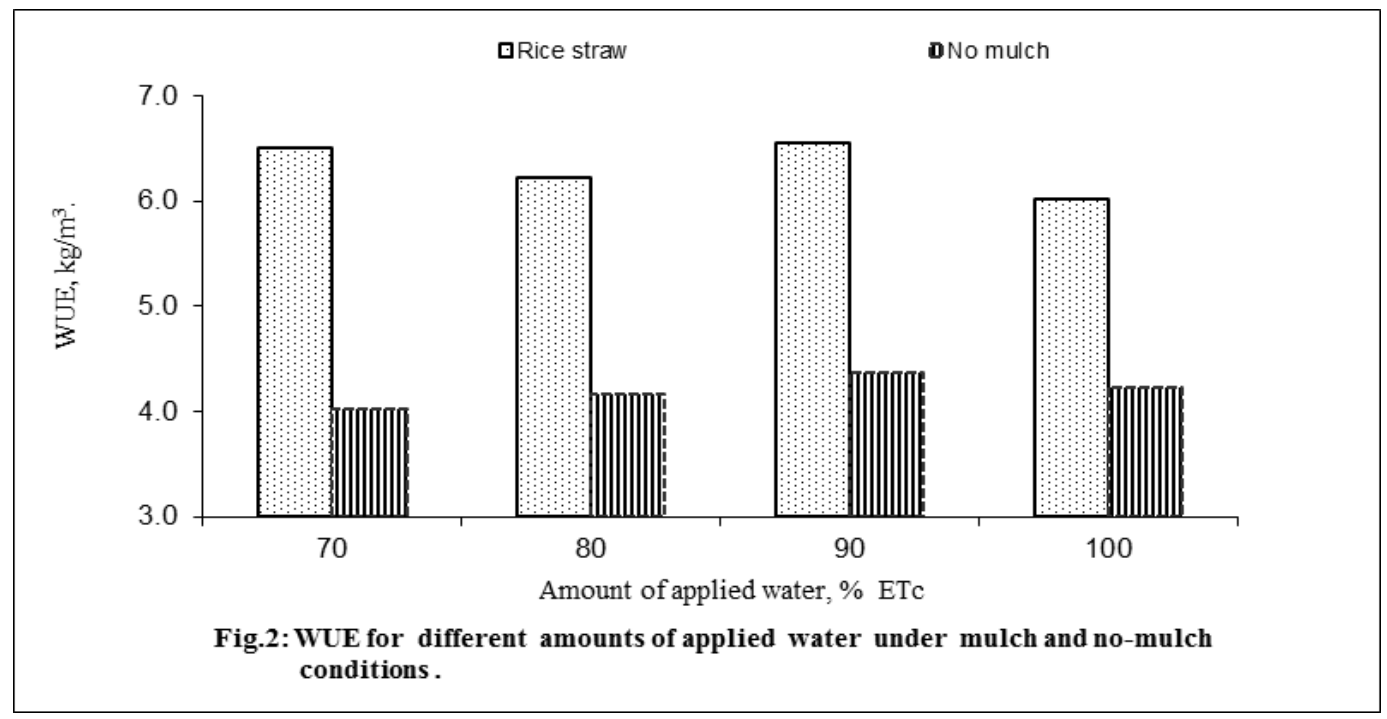

\section{Costs analysis.}

Results illustrated in Table 6 for no-mulch and rice straw mulch show that the maximum $\mathrm{B} / \mathrm{C}$ ratio under no-mulch was 2.65 with $100 \%$ of water requirements while it was 3.59 for rice straw treatment with $90 \%$ of $\mathrm{ET}_{\mathrm{c}}$. Despite the addition cost of rice straw mulching operation. The treatments under rice straw mulch gave higher values of $\mathrm{B} / \mathrm{C}$ ratio, That may lead to economically recommend rice straw mulching under experimental variables and conditions. 
Table.6: Total costs for 5 feddans under mulch and no-mulch treatments.

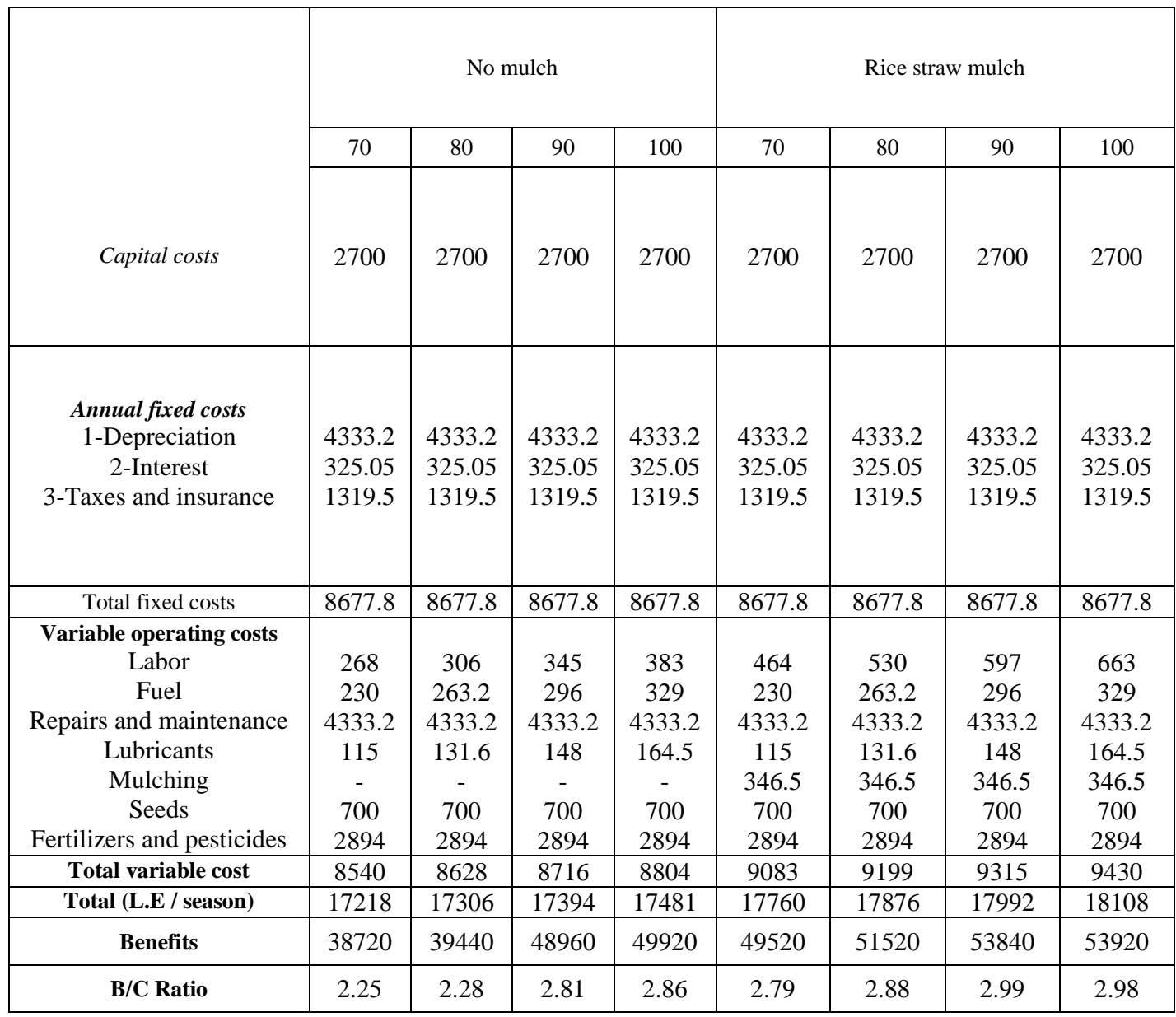

\section{CONCLUSION}

Rice straw mulching led to increase crop productivity and did not give significant reduction in crop productivity. Crop water productivity showed that the most benefit of unit of water was with $90 \%$ of $\mathrm{ET}_{\mathrm{c}}$. The maximum $\mathrm{B} / \mathrm{C}$ ratio was under the same previously mentioned treatment. That may lead to recommend using rice straw for cucumber crop irrigated by drip irrigation system under sandy soil conditions every 48 hours with $90 \%$ of $\mathrm{ET}_{\mathrm{c}}$ to obtain an increase in the product of unit of water and $\mathrm{B} / \mathrm{C}$ ratio.

\section{REFERENES}

Abd El-Kader, N., A. Derbala and M. E. M. Ahmed. (2010). Influence of Mulching and Some Micro-nutrients Usage on Soil Temperature, Soil Moisture, Growth and Cowpea Yield. Research Journal of Agriculture and Biological Sciences, 6(4): 505-513, 2010 
Al-Wahaibi, N. S., N. Hussain and S.A. Al-Rawahy.(2007). Mulching for sustainable use of saline water to grow tomato in Sultanate of Oman. Sci. Int., 19: 79-81.

Bu, Y.S., B. Svensson and J.C. Wang.(2002). Effects of different mulch materials on corn seedling growth and soil nutrient contents and distributions. J. Soil Water Cons., 16: 40-42.

Buchanan, R.J.,and T.L. Cross (2002). Irrigation Cost Analysis Hand Book.Agricultural Extension Service.The University of Tenessee.PB1721

El-Dnasoury, M. M. (2001). Farm machinery, types and performance evaluation methods (in Arabic). Academic library, Cairo, Egypt.

FAO (1993). CIIMWAT for CROPWAT. FAO Irrigation and drainage paper No.49.

FAO (1998).Crop evapotranspiration - Guidelines for computing crop water requirements - FAO Irrigation and drainage paper No 56.

Jensen, M. E.(1983).Design and operation of farm irrigation systems.ASAE, Michigan ,USA.p827.

Kar, G. and A. Kumara. (2007). Effects of irrigation and straw mulch on water use and tuber yield of potato in eastern India. Sci. Direct-Agric. Water Manage., 94: 109-116.

Keller, J. and D. Karmeli (1975). Trickle irrigation design, Rain Bird Sprinkler. Mfg. Co. Gleendora, Calif., USA: 133.

Kepner, R. A. Bainer ,R. and E. L. Barger (1980).Principles of farm machinery,pupl.hing Co.INC ,N.Y.

Kirda , C; Moutonnet, P; Hera, C. and D. R. Nielsen (1999).Crop yield response to deficit irrigation scheduling based on plant growth stages showing water stress tolerance. Dordrech, The Netherlands,kluwer academic publishers.

Naryan,T.A.;S. Thimmegowda;A.G.Bandi and N.Devakumar (1994). Economic Feasibility of Adopting Drip Irrigation in Sweet Pepper ( Capsicum Frutescenes var.Grossum).Indian J.Agron.39(1):150-151.

Olson,S.M.(1995).Mulching.University of florida,institute of food and agricultural science.(online document )available :<http:edis.ifas.ufl.edu/body_cv105\#copy.( September 25,2004).

Rahaman,M.J.; M.Shalim Uddin, M.J. Uddin, Shamim Ara Bagum, N.K. Halder and M.F. Hossain (2004).Effect of Different Mulches on 
Potato at the Saline Soil of Southeastern Bangladesh. Journal of Biological Sciences 4 (1): 1-4, 2004ISSN 1727-3048.

Vermeiren, L. and G.A. Jobling (1980). Localized irrigation- Design, installation, operation and evaluation. FAO irrigation and drainage paper 36. FAO, Rome.

Yang, Y., L. Xiao-Jing, L. Wei-Qiang and L. Cun-Zhen. (2007). Effect of different mulch materials on winter wheat production in desalinized soil in Heilonggang region of North China. J. Zhejiang Univ. Sci. B., 7: 858-867.

\section{الملخص العربي}

التشغيل الاقتصادي لنظام الرى بالتنقيط باستخدام التغطية بقش الأرز

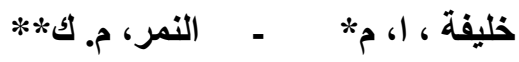

جريت تجربة بمزرعة واحة النجاه بقرية الخطاطبة - مدينة السادات ـ محافظة المنوفية في عام

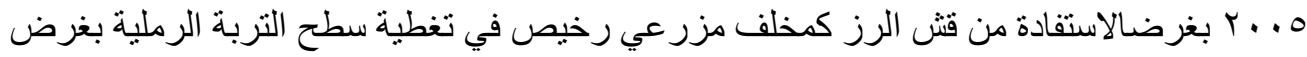

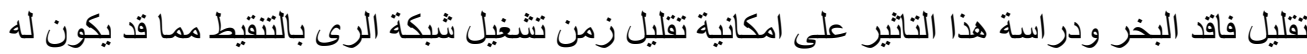

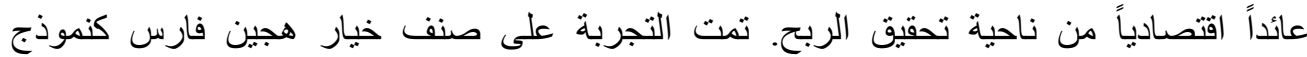

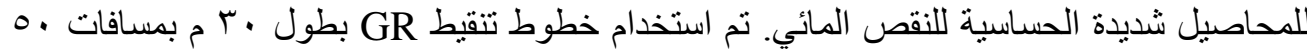

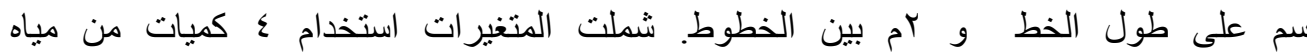

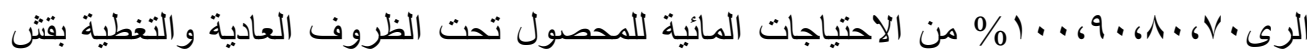

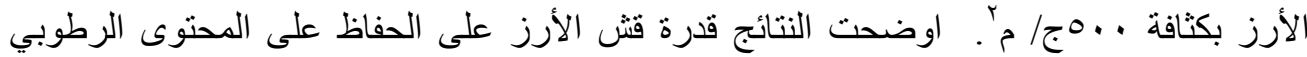

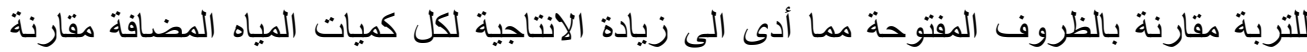

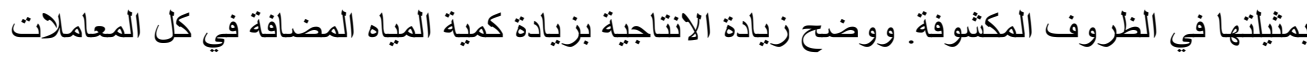

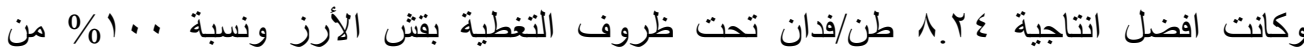

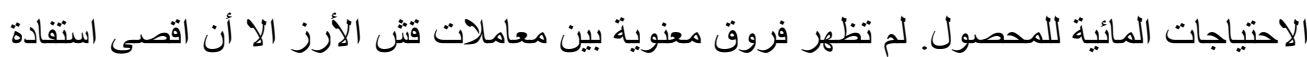

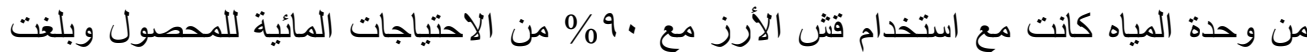

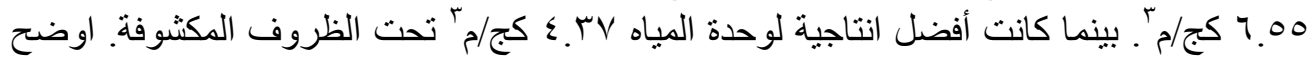

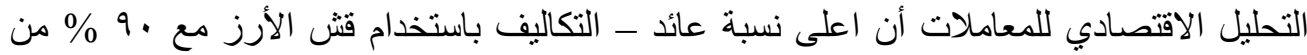

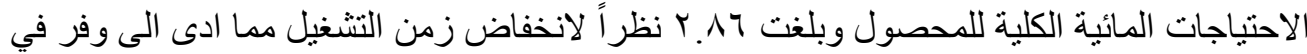

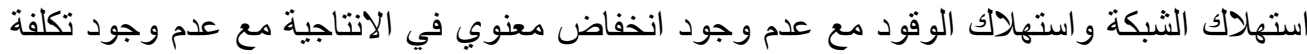

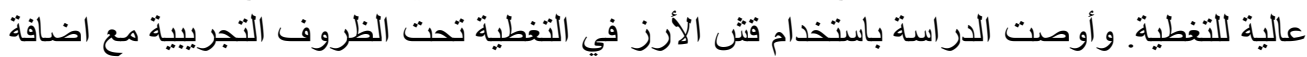

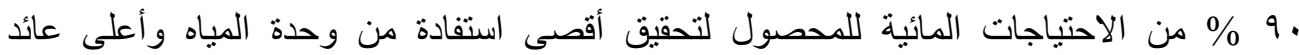
اقتصادي.

*أستاذ مساعد بقسم الهندسة الزراعية_كلية الزراعة جاعة جامعة كفر الثيخ. **مدرس بقسم الهندسة الزراعية ـ كلية الزراعة ـ جامعة كفر الثيخ. 